\title{
Peran Pendidikan Islam terhadap Pembentukan Karakter Disiplin Peserta Didik
}

\author{
Unik Hanifah Salsabila ${ }^{1}$, Annisa Septarea Hutami ${ }^{2}$, Safira Aura Fakhiratunnisa ${ }^{3}$, \\ Wulan Ramadhani ${ }^{4}$, Yuike Silvira ${ }^{5}$ \\ ${ }^{12345}$ Universitas Ahmad Dahlan \\ Iunik.salsabila@pai.uad.ac.id, ${ }^{2}$ shashaesha92@gmail.com, ${ }^{3}$ safiraaura91@gmail.com, \\ ${ }^{4}$ wulanrhamadhani30@gmail.com, ${ }^{5}$ yuikesilivira33@gmail.com
}

\begin{abstract}
This paper presents the role of islamic education in order to characterize the discipline of students. There are still many students in public schools underestimate matters related to discipline such as morals, manners, behavior or others. Therefore, islamic education is the key and the best solution in the prescription of disciplinary character in students where Islamic education is a process of deepening and appreciating knowledge in which there are Islamic values given to students through the growth and development of their natural potential in order to arrive at equality and the perfection of his life. The research method used in this research is descriptive analysis by collecting data and sources to be analyzed, then interpreted critically and presented more systematically about islamic education to order the character of discipline in students. The results showed that the character of discipline in students can be formed by the role of islamic education, including through the provision of religious materials, habits, advice, admonitions, and exemplary examples from educators.
\end{abstract}

Key Word: Discipline Character, Islamic Education, Learners

\begin{abstract}
Abstrak
Tulisan ini menyajikan tentang bagaimana peran pendidikan Islam terhadap pembentukan karakter disiplin pada peserta didik. Masih banyak peserta didik di sekolah umum menyepelekan hal-hal yang terkait dengan kedisiplinan di antaranya akhlak, tata krama, tingkah laku, atau yang lainnya. Oleh sebab itu, pendidikan Islam menjadi kunci dan solusi terbaik dalam pembentukan karakter disiplin pada peserta didik di mana pendidikan Islam merupakan proses pendalaman serta penghayatan ilmu yang di dalamnya terdapat nilai-nilai keislaman yang diberikan kepada peserta didik melalui pertumbuhan dan perkembangan potensi fitrahnya agar dapat sampai pada kesetaraan serta kesempurnaan hidupnya. Metode penelitian yang digunakan dalam penelitian ini ialah analisis deskriptif yakni dengan mengumpulkan data serta sumber untuk dianalisis, kemudian diinterpretasi dengan kritis dan disajikan secara lebih sistematik mengenai peran pendidikan Islam terhadap pembentukan karakter disiplin dalam peserta didik. Hasil penelitian menunjukkan bahwa karakter disiplin pada peserta didik dapat dibentuk dengan adanya peran pendidikan Islam di antaranya melalui pemberian materi keagamaan, pembiasaan, nasehat, teguran, serta keteladanan yang dicontohkan pendidik.
\end{abstract}

Kata Kunci: Karakter Disiplin, Pendidikan Islam, Peserta Didik 


\section{Pendahuluan}

Dampak buruk globalisasi membawa generasi muda kehilangan nilai moralnya. Budi pekerti luhur, kejujuran, kesantunan, rasa hormat dan akhlak mulia lainnya seolah-olah kian memudar dan terasa asing di kalangan generasi muda. Masalah kemunduran karakter tersebut masih banyak dijumpai pada anak-anak sekolah yang mana sikap dan perilakunya bertentangan dengan nilai agama dan etika yang ada. Salah satu contohnya ialah perilaku disiplin yang tidak lagi tercermin pada peserta didik di lembaga pendidikan. Maka untuk itu, diperlukan usaha dalam mendapatkan kembali nilai karakter disiplin dalam peserta didik melalui pendidikan karakter.

Karakter ialah penilaian sikap manusia yang berkaitan kepada sang pencipta (tuhan), antar manusia, dan pada diri kita sendiri, lingkungan, serta bangsa yang terbentuk di dalam rohani, logika, kelakuan, serta tingkah laku berdasar pada nilai-nilai hukum, agama, tata krama, adat istiadat dan estetika. Karakter diartikan dengan tingkah laku, sikap ataupun perbuatan yang terlihat di dalam

1 Muchlas Samani and Hariyanto, "Konsep Dan Model Pendidikan Karakter,” Bandung: PT Remaja Rosdakarya, 2011. "Internalisasi Nilai-Nilai Pendidikan Islam Dalam keseharian. ${ }^{1}$ Karakter tidak cuma menjadi sebuah tabiat atau bawaan lahir, tetapi lebih dari itu bahwa karakter merupakan identitas diri yang dapat dibentuk sedemikian rupa melalui pembiasaan dan beberapa kegiatan positif. $^{2}$

Pendidikan Islam menjadi opsi satusatunya yang bisa dikerjakan dalam pembentukan perilaku peserta didik di sekolah. Muhaimin mengemukakan bahwa pendidikan Islam merupakan pembelajaran yang dapat dimengerti dan diuraikan dari pembelajaran serta penilaian fundamental yang terdapat pada Al-Qur'an dan AsSunnah. Pendidikan Agama Islam merupakan sebuah metode peningkatan kemampuan manusia ke arah terciptanya manusia yang sejati dan berkarakter islami (memiliki perangai yang cocok dengan nilai keislaman). ${ }^{3} \quad$ Tujuan penting dari pendidikan Islam yakni membentuk watak atau budi pekerti pada peserta didik yang tampak pada perilaku dan juga cara pandangnya pada kehidupan kesehariannya.

Tujuan pendidikan Islam bukan sekedar untuk memenuhi kebutuhan intelektual saja, akan tetapi baik dari sisi

Pembentukan Karakter Siswa SMP," Jurnal Pendidikan Islam 3, no. 2 (2019): 247-269.

3 Syamsul Huda Rohmadi, Pengembangan Kurikulum Pendidikan Agama Islam, Yogyakarta: Araska, 2012. 
Peran Pendidikan Islam terhadap Pembentukan Karakter

Disiplin Peserta Didik

Oleh: Unik H Salsabila, Annisa S Hutami, Safira A

Fakhiratunnisa, Wulan Ramadhani, Yuike Silvira

pendalaman juga pengamalan serta penerapannya dalam kehidupan. Dalam pendidikan Islam, proses pendalaman yang sesungguhnya terhadap moralitas menjadi patokan keberhasilan. Apabila seorang peserta didik dalam pendidikannya mendapatkan pengetahuan agama yang baik, terlebih ia mengerti dan paham terhadap pengetahuan yang didapatnya, maka banyak peluang peserta didik tersebut akan mampu menerapkan ilmu yang dimilikinya tersebut.

Pembinaan karakter dapat dibangun melalui pengaruh lingkungan terutama pendidikan. Pribadi dengan akhlak yang mulia menjadi sasaran yang dituju dalam pembentukan karakter ini. Dalam pembentukan karakter peserta didik, seharusnya setiap pendidik menyadari bahwa dalam pembentukan karakter dibutuhkan pembimbing dan pelatihan akhlak pada peserta didik yang tidak hanya diberikan secara teoritis, namun harus diajarkan ke arah kehidupan praktis. Peran pendidikan Islam ialah sebagai pengendali perilaku atau tindakan yang muncul dari kecenderungan yang beralaskan emosi. Apabila peserta didik telah membiasakan ajaran agama menjadi penuntun dalam kehidupan sehari-hari dan telah ditanamkannya sedari dini, maka

\footnotetext{
4 Aulia Rachman and Murniati Agustian, "Meningkatkan Kedisiplinan Siswa Melalui
}

perilakunya akan lebih mudah dalam mengendalikan hasrat buruk yang muncul.

Menurut Aulia Rachman dan Murniati Agustian melalui observasi siswa kelas IV A SDN 23 Pagi Palmerah Jakarta Pusat menyebutkan bahwa kedisiplinan siswa masih kurang dalam mengikuti kegiatan pembelajaran, sebagaimana pada saat proses belajar mengajar berlangsung banyak peserta didik yang mengganggu teman lainnya, ketidakpatuhan peserta didik pada guru ketika berada di dalam kelas, mengobrol sendiri dengan teman sebangku. ${ }^{4}$ Masalah-masalah kedisiplinan pada peserta didik lainnya ialah melakukan kegaduhan ketika pembelajaran yang menyebabkan ketidakpahaman peserta didik terhadap materi pelajaran yang disampaikan oleh guru, peserta didik tidak tepat waktu seperti terlambat datang ke sekolah dan masih banyak lagi masalah kedisiplinan lainnya.

Dilihat dari pengertian, tujuan serta harapan dari pendidikan Islam terhadap pembentukan karakter disiplin peserta didik, maka diharapkan peranan pendidikan Islam tersebut mampu mengatasi masalahmasalah kedisiplinan yang ada pada peserta didik. Sehingga penulis meyakini bahwa karakter disiplin yang terbentuk sesuai dengan tujuan pendidikan Islam akan Jakart," Jurnal Perkotaan 8, no. 2 (2016): 75-93. 
Peran Pendidikan Islam terhadap Pembentukan Karakter

Disiplin Peserta Didik

Oleh: Unik H Salsabila, Annisa S Hutami, Safira A

Fakhiratunnisa, Wulan Ramadhani, Yuike Silvira

memiliki pengetahuan yang dapat

diterapkan pada keseharian peserta didik.

Namun pada kenyataannya, peranan

pendidikan Islam di sekolah-sekolah belum

diterapkan dengan baik dan maksimal

sehingga masih banyak ditemui peserta

didik yang kurang disiplin dalam berbagai

hal dan akan menjadi kebiasaan buruk yang

terus berlanjut apabila tidak ditangani. ${ }^{5}$

Tetapi paling tidak terdapat sedikit karakter disiplin yang peserta didik tunjukkan melalui perilakunya di kehidupan sehari-hari sebagai hasil dari terserapnya nilai-nilai dari karakter disiplin pada peserta didik. Nilai-nilai yang dimaksudkan yaitu seperti datang ke sekolah dengan tepat waktu, sebelum memasuki kelas peserta didik melakukan apel pagi dilanjutkan dengan masuk ke kelas masing-masing dengan tertib. ${ }^{6}$

Dari pemaparan di atas, maka lembaga pendidikan perlu mengembangkan peranan pendidikan Islam guna menciptakan dan membentuk karakter disiplin pada peserta didik dalam kehidupan sehari-hari yang dilaksanakan melalui pembelajaran di sekolah. Demikian problematika yang ada, yang menjadikan jadi penulis terdorong untuk menelaah lebih

5 Fadillah Annisa, "Penanaman Nilai-Nilai Pendidikan Karakter Disiplin Pada Siswa Sekolah Dasar," Perspektif Pendidikan Dan Keguruan 10, no. 1 (2019): 69-74.

m 6 Nur Rahmat, Sepriadi Sepriadi, and Rasmi

๗ Daliana, "Pembentukan Karakter Disiplin Siswa lanjut tentang peran pendidikan Islam terhadap pembentukan karakter disiplin pada peserta didik.

\section{Metode Penelitian}

Penelitian ini menggambarkan penelitian kualitatif yang bersifat kepustakaan (library research), maka akar dari data penelitian ini merupakan data-data kepustakaan. Melalui metode penelitian kualitatif, maka peneliti melakukan analisis deskriptif. Metode analisis deskriptif dilakukan dengan proses menuangkan penjelasan serta gambaran yang sejelasjelasnya secara terpadu, kritis, objektif serta analitik tentang peran pendidikan Islam terhadap pembentukan karakter disiplin dalam peserta didik. Berdasarkan situasi tersebut, tahap pertama yang dapat dilakukan ialah mengumpulkan data-data yang diperlukan, setelah itu diklasifikasikan dan dideskripsikan.

Data dikumpulkan dengan cara dengan mencari, memilih, menerangkan dan menganalisis data-data literatur atau sumber-sumber yang berkenaan dengan topik yang dibahas. Adapun data primer dalam penelitian ini adalah buku mengenai teori pendidikan dalam Islam, teori

Melalui Guru Kelas Di Sd Negeri 3 Rejosari Kabupaten Oku Timur," JMKSP (Jurnal Manajemen, Kepemimpinan, Dan Supervisi Pendidikan) 2, no. 2 (2017): 229-244. 
Peran Pendidikan Islam terhadap Pembentukan Karakter Disiplin Peserta Didik

Oleh: Unik H Salsabila, Annisa S Hutami, Safira A

Fakhiratunnisa, Wulan Ramadhani, Yuike Silvira

mengenai pembentukan karakter disiplin, dan teori mengenai peserta didik. Sumber sekunder dari penelitian ini adalah jurnaljurnal serta literatur-literatur kepustakaan yang dapat menunjang analisis atau berkenaan dengan pembahasan.

Selanjutnya, analisis data adalah aktifitas memfokuskan, mengabstraksikan, mengelola data secara runtut, terpadu, dan logis untuk memberikan bahan jawaban terhadap penelitian. Metode deskriptifanalitik dalam penelitian ini maksudnya sebagai metode penelitian yang sumbersumbernya dikumpulkan, dianalisis, setelah itu barulah diinterpretasi dengan kritis kemudian disajikan secara lebih sistematik dan menambahkan penjelasan-penjelasan yang berkesinambungan sehingga bisa lebih mudah dalam memahaminya dan memberikan kesimpulannya. Hal tersebut dilakukan untuk memperoleh penjelasan, keterangan serta gambaran yang utuh dan benar berdasarkan objek yang diteliti.

\section{Hasil Penelitian dan Pembahasan}

\section{Karakter Disiplin}

Karakter menurut Kamus Besar Bahasa Indonesia (KBBI) berarti sifat budi pekerti, akhlak, tingkah laku, sifat-sifat kejiwaan, yang membedakan antara orang

\footnotetext{
7 Departemen Pendidikan Nasional, Kamus Besar Bahasa Indonesia, Jakarta: Gramedia Pustaka Utama, 2019.
}

yang satu dengan yang lainnya. ${ }^{7}$ Karakter juga bisa didefinisikan sebagai sifat alami seseorang dalam menanggapi keadaan secara bermoral yang terbentuk dari hasil internalisasi berbagai kebajikan yang diyakini sebagai dasar dalam berpikir, bersikap, dan bertindak. ${ }^{8}$ Dalam perspektif Islam karakter dimaknai sebagai akhlak. Karakter atau akhlak diyakini sebagai kebiasaan berkehendak yang berarti apabila seseorang membiasakan suatu ucapan ataupun tindakan maka kebiasaan itu disebut akhlak.

Berdasarkan beberapa pengertian tersebut, karakter serupa dengan akhlak, sehingga karakter dapat dimaknai sebagai manifestasi dari nilai-nilai tingkah laku manusia yang universal dan mencakup seluruh kegiatan manusia, baik hubungan antar manusia dengan tuhan (hablumminallah), hubungan antar sesama manusia (hablumminannas) dan hubungan manusia dengan lingkungannya.

Disiplin yaitu suatu kondisi yang terbentuk melalui proses dan serangkaian tingkah laku yang memperlihatkan pada nilai-nilai dari ketertiban, kepatuhan, serta kesetiaan. Seseorang dengan disiplin yang tinggi biasanya akan selalu hadir dengan tepat waktu, patuh kepada aturan yang

\footnotetext{
${ }^{8}$ Agus Wibowo, "Manajemen Pendidikan Karakter Di Sekolah,” Yogyakarta:Pustaka Pelajar, 2017.
} 
Peran Pendidikan Islam terhadap Pembentukan Karakter Disiplin Peserta Didik

Oleh: Unik H Salsabila, Annisa S Hutami, Safira A

Fakhiratunnisa, Wulan Ramadhani, Yuike Silvira

berlaku, memiliki perilaku sesuai dengan hukum yang berlaku, dan sebagainya. Akan tetapi apabila sesorang yang memiliki disiplin rendah biasanya tidak mampu untuk mematuhi aturan-aturan yang berlaku, baik itu asalnya dari masyarakat (konvensi-informasi) maupun dari aturan yang ditetapkan oleh suatu lembaga atau pemerintah (organisasional-formal). ${ }^{9}$

$$
\text { Disiplin dimaknai sebagai }
$$

penertiban perilaku-perilaku manusia sesuai dengan ajaran yang dianutnya. Penertiban perilaku tersebut yakni kepatuhan dan ketaatan seseorang pada penertiban perilaku yang biasanya dibangun dalam bentuk peraturan lainnya atau tata tertib. Selain itu seseorang bisa disebut berdisiplin apabila orang tersebut patuh pada penertiban yang dirumuskan dalam bentuk hukum-hukum yang berlaku pada instansi tertentu. Pernyataan sikap mental dari seseorang ataupun masyarakat yang menggambarkan rasa kepatuhan, ketaatan yang didukung oleh kesadaran untuk menjalankan tugas dan kewajiban dalam rangka pencapaian tujuan. Tujuan disiplin tersebut berkaitan dengan pengendalian diri terhadap bentuk-bentuk aturan serta penertiban perilaku agar

9 Kurniawan Syamsul, "Pendidikan Karakter," Yogyakarta: Ar-Ruzz Media, 2014. menjadi individu yang baik sesuai dengan

status sosial kelompok masyarakat. ${ }^{10}$

\section{Pendidikan Islam}

Pendidikan adalah kunci utama dan suatu kebutuhan dasar dalam kehidupan. Pendidikan wajib bagi setiap manusia entah itu pendidikan formal atau non formal, karena dengan pendidikan manusia dapat membedakan hal buruk atau pun hal baik. Pendidikan adalah bekal utama dalam kehidupan. Tanpa pendidikan dalam kehidupan bagaikan rumah tanpa tiang. Terutama pendidikan Islam, karena pada dasarnya pendidikan Islam melambangkan upaya untuk pembinaan dan perkembangan potensi manusia, supaya kehadiran kita di dunia sekarang ini bertujuan sebagai hamba Allah SWT dan juga sebagai khalifahnya bisa tercapai semaksimal mungkin. Potensi tersebut yaitu potensi jasmaniah dan potensi rohaniah yang meliputi, kehendak, akal, perasaan, dan yang lainnya. Pendidikan Islam mampu menjadi sebuah upaya dalam memberikan jasa pendidikan pada lembaga kemasyarakatan bahkan dapat menjadi usaha manusia untuk dirinya sendiri.

Pendidikan Islam ialah sebuah proses transformasi dan internalisasi ilmu pengetahuan yang di dalamnya terdapat

Peserta Didik Kelas VI MIS GUPPI Laikang Kecamatan Kajang Kabupaten Bulukumba," Jurnal Inspiratif Pendidikan 7, no. 2 (2018): 233-252. 
Peran Pendidikan Islam terhadap Pembentukan Karakter

Disiplin Peserta Didik

Oleh: Unik H Salsabila, Annisa S Hutami, Safira A

Fakhiratunnisa, Wulan Ramadhani, Yuike Silvira

nilai-nilai keislaman yang diberikan kepada peserta didik lewat pertumbuhan juga perkembangan kemampuannya agar bisa mencapai keseimbangan dan keutuhan hidupnya. Di lingkup pendidikan Islam sendiri terdapat sebuah proses untuk memberi bimbingan kepada peserta didik agar bisa meningkatkan keimanan mereka dan mengubah kepribadian mereka menjadi lebih baik, supaya mereka siap menghadapi kehidupan lebih baik juga di generasi selanjutnya yang berdasarkan syariat Islam. $^{11}$

Tujuan umum dari pendidikan Islam adalah untuk menjadikan manusia sebagai hamba Allah SWT. Tujuan pendidikan Islam sejalan dengan tujuan yang diciptakan oleh manusia sendiri, yaitu memperbaiki jalan pikiran manusia dan memperbaiki akhlak dan juga jiwanya yang sesuai dengan syariat Islam. Dan tujuan sebenarnya dari pendidikan Islam ialah merealisasikannya kepada Allah SWT di dalam kehidupan manusia, baik secara individu maupun orang lain. Pendidikan Islam dapat membentuk akhlak dan juga budi pekerti yang lebih baik agar bisa menghasilkan keturunan-keturunan lebih baik dan bermoral, memiliki jiwa yang suci,

11 Ridlwan Nasir, "Mencari Tipologi Format Pendidikan Ideal: Pondok Pesantren Di Tengah Arus Perubahan," Yogyakarta:Pustaka Pelajar, 2010.

${ }^{12}$ H Suhada, Arief Saptono, and Ageng Setiani Rafika, "Pengaruh Pendidikan Agama Islam bertekad, mengetahui arti dari kewajiban dan penerapannya, menghormati sesama, mampu membedakan yang buruk dan yang baik, memilih suatu fadilah karena cinta pada fadilah, menghindari perbuatan yang tercela, dan selalu ingat kepada sang pencipta dalam keadaan apapun. ${ }^{12}$

Adapun yang dimaksud dengan metode pendidikan ialah merupakan segala upayah yang digunakan untuk pembelajaran. Arti "metode" ini secara umum. Sebab kegiatan mengajar merupakan sebuah upaya dalam mendidik, jadi metode di sini ialah sebuah cara pengajaran yang baik dan juga benar dan cocok. Ada beberapa metode yang menjadi ciri khas dalam pendidikan Islam, untuk menumbuhkan rasa keimanan, di antaranya ialah metode hiwar, kisah qurani dan nabawi, metode amsal qurani dan nabawi, keteladanan, pembiasaan, ibrah dan mauizah, dan yang terakhir targhib dan juga tarhib. ${ }^{13}$

\section{Peserta Didik}

Peserta didik merupakan pribadi yang memiliki kemampuan untuk berkembang, dan berusaha mengembangkan kemampuan tersebut

Terhadap Perilaku Akhlak Siswa (Karakter)," Jurnal Cices 4, no. 2 (2018): 228-244.

${ }^{13}$ Ahmad Tafsir, Ilmu Pendidikan Dalam Perspektif Islam, Bandung: PT Remaja Rosdakarya, 2014. 
Peran Pendidikan Islam terhadap Pembentukan Karakter

Disiplin Peserta Didik

Oleh: Unik H Salsabila, Annisa S Hutami, Safira A

Fakhiratunnisa, Wulan Ramadhani, Yuike Silvira

melalui upaya pendidikan melalui jalan serta jenis pendidikan tertentu. Maka dari itu, pemenuhan kebutuhan peserta didik dalam masa tumbuh kembangnya perlu diperhatikan sebaik mungkin sehingga dapat mencapai kematangan fisik dan psikisnya.

Peserta didik dalam pandangan pendidikan Islam ialah pribadi yang sedang tumbuh dan berkembang, baik dari segi fisik maupun psikis dalam upaya mencapai tujuan pendidikan. Sedangkan dalam bahasa Arab, peserta didik disebut dengan istilah tilmidh (untuk peserta didik pada sekolah dasar) dan thalib al-ilm (untuk peserta didik pada sekolah menengah pertama, menengah atas, dan perguruan tinggi).

Menurut Maragustam, peserta didik dalam pendidikan Islam merupakan bagian dari masyarakat yang berupaya untuk mengembangkan dirinya melalui proses pendidikan serta menjadi individu yang memiliki iman, ilmu, takwa, dan berakhlak mulia sehingga dapat melaksanakan kewajibannya sebagai hamba Allah SWT dan sebagai khalifah di bumi. ${ }^{14}$ Dalam upaya untuk mencapai tujuan pendidikan, peserta didik harus memiliki serta menegakkan sifat-sifat yang baik dari

${ }^{14}$ Maragustam Siregar, Filsafat Pendidikan Islam: Menuju Pembentukan Karakter Menghadapi Arus Global, Yoyakarta: Kurnia Kalam Semesta, 2015. kepribadiannya. Sifat-sifat tersebut di antaranya ialah pantang menyerah, memiliki motivasi tinggi, tabah, sabar, serta tidak mudah putus asa.

Hal-hal yang berkaitan dengan karakteristik peserta didik di antaranya ialah peserta didik bukanlah miniatur orang dewasa, mereka memiliki dunianya sendiri; peserta didik memiliki kebutuhan dan menuntut terpenuhinya kebutuhan tersebut; peserta didik memiliki perbedaan antara peserta didik yang satu dengan yang lain; peserta didik merupakan subjek dan objek dalam pendidikan; dan peserta didik mengikuti periode-periode perkembangan tertentu. ${ }^{15}$

\section{Analisis Pembahasan}

\section{Pembentukan Karakter Disiplin pada Peserta Didik}

Ada beberapa istilah tentang pendidikan karakter yaitu biasa disebut dengan pendidikan kewarganegaraan, pendidikan nilai dan juga pendidikan moral. Istilah-istilah tersebut dapat menunjuk pada sesuatu hal baik yang dapat manusia kembangan di dalam dirinya, sehingga mampu membentuk karakter. Segenap entitas yang berkenaan dengan hal baik tersebut mempunyai sifat dasar yang

15 Abdul Mujib and Jusuf Mudzakkir, Ilmu Pendidikan Islam, Jakarta: Kencana Prenada Media Group, 2007. 
Peran Pendidikan Islam terhadap Pembentukan Karakter

Disiplin Peserta Didik

Oleh: Unik H Salsabila, Annisa S Hutami, Safira A

Fakhiratunnisa, Wulan Ramadhani, Yuike Silvira

tetap, maksudnya adalah tetap sama dari waktu ke waktu. Sebagai contoh, sikap displin dan jujur merupakan sebuah hal yang baik dari zaman dahulu sampai saat ini. Maka dari itu pendidikan karakter harus tetap diajarkan dan dilakukan agar memberikan pengaruh yang positif pada manusia terutama peserta didik. Setiap individu pada lembaga pendidikan pada dasarnya belajar hidup bersama serta mengasah kepekaan moral mereka. Maka dari itu lingkup sekolah merupakan fokus pendidikan yang amat penting. Agar dapat menjadi manusia yang bermoral, maka diperlukan kedisiplinan diri dan ketetapan pada prinsip-prinsip moral yang dipercayai bahwa itu benar. ${ }^{16}$ Disiplin akan menjadikan peserta didik mengerti dan mampu memilah hal-hal yang wajib dilakukan, tidak boleh dilakukan, seharusnya dilakukan serta hal-hal yang dilarang untuk dilakukan. Bagi peserta didik yang sudah menyatu dengan disiplin di dalam dirinya, maka mereka tidak akan merasakan beban saat melakukannya tetapi hal yang sebaliknya mereka akan merasakan beban apabila tidak disiplin. ${ }^{17}$

Pembentukan karakter adalah suatu proses menanamkan hal-hal positif ke

16 Yoyo Zakaria Ansori, "Penguatan Karakter Disiplin Siswa Melalui Peranan Guru Di Sekolah Dasar," Jurnal Elementaria Edukasia 3, no. 1 (2020): 126-135. dalam diri peserta didik baik di lingkungan keluarga, masyarakat, dan sekolah. Pembentukan karakter di keluarga yang berperan penting adalah orang tua yang di mana orang tua harus membiasakan hal-hal baik dalam kehidupan sehari-hari. Lalu pembentukan karakter di lingkungan masyarakat, bila hidup di lingkungan yang positif maka berdampak baik bagi kehidupan dan sebaliknya bila hidup di lingkungan yang negatif atau kurang baik maka akan menimbulkan beberapa dampak buruk bagi kehidupan. Ppembentukan karakter di sekolah yang di mana seorang figur sangat berperan penting dalam hal ini yaitu guru. Guru berperan untuk mendidik moral dan kualitas peserta didik. Maka pendidikan itu sangat penting dalam pembentukan karakter peserta didik.

Disiplin dapat membantu peserta didik dalam menghindari perilaku yang menyimpang sebab dalam disiplin diajarkan untuk membiasakan diri berperilaku baik sehingga peserta didik mampu hidup dengan kebiasaan-kebiasaan yang baik. Dalam membentuk karakter seorang peserta didik membutuhkan waktu dan komitmen dari pihak orang tua maupun pihak sekolah dalam membentuk peserta

\footnotetext{
17 Suradi, "Pembentukan Karakter Siswa Melalui Penerapan Disiplin Tata Tertib Sekolah," BRILIANT: Jurnal Riset Dan Konseptual 2, no. 4 (November 13, 2017): 522-533, https://doi.org/10.28926/briliant.
} 
Peran Pendidikan Islam terhadap Pembentukan Karakter Disiplin Peserta Didik

Oleh: Unik H Salsabila, Annisa S Hutami, Safira A

Fakhiratunnisa, Wulan Ramadhani, Yuike Silvira

didik berkarakter disiplin. Sebab disiplin tidak dapat terbentuk secara instan, melainkan melalui proses dan kebiasaan yang ditanamkan sejak dini agar dapat melekat pada diri seorang peserta didik. Maka dari itu, pihak sekolah harus menerapkan pembiasaan disiplin agar menciptakan suasana dan lingkungan yang baik.

Penerapan disiplin ini dapat berkembang jika ada faktor pendukung seperti keterlibatan orang tua. Keterlibatan orang tua dalam pembentukan karakter disiplin pada peserta didik sangatlah penting, sebab dapat mengawasi dan mengontrol perilaku peserta didik saat di rumah. Seperti orang tua mendisiplinkan anak dalam hal belajar dan bermain, beribadah, menonton televisi dan sebagainya. Apabila terdapat perilaku menyimpang pada peserta didik, orang tua sebaiknya memberitahu pihak sekolah akan hal tersebut agar mampu mencari solusinya sehingga perilaku menyimpang yang dilakukan peserta didik dapat teratasi dan peserta didik mampu menaati kembali peraturan yang ada.

\section{Peran Pendidikan Islam dalam}

Pembentukan Karakter Disiplin pada

\section{Peserta Didik}

Pendidikan Islam pada hakikatnya berupaya untuk mampu dalam membina akhlak dan menanamkan sikap disiplin atau sikap positif lainnya kepada peserta didik. Pendidikan Islam juga berupaya untuk menggali dan membina, membentuk dan mengarahkan peserta didik untuk senantiasa berbuat atau berakhlak terpuji sehingga pendidikan Islam bisa dikatakan memiliki fungsi sebagai pendidikan karakter. Pendidikan Islam bisa ditemukan di beberapa tempat asalkan tetap berada dalam lingkungan positif. Peserta didik perlu meningkatkan kesadaran agar mereka mampu mematuhi peraturan yang ada dan bersikap disiplin. Pendidikan Islam sangat menegaskan hal terkait akhlak salah satunya kedisiplinan. Setiap manusia di muka bumi ini harus memiliki sikap disiplin, jika tidak akan membawa hal buruk pada dirinya sendiri. Maka peserta didik pun harus belajar untuk bersikap disiplin melalui pendidikan Islam.

Adapun pembelajaran pendidikan agama Islam memiliki tujuan yang utama yakni adanya pembentukan karakter peserta didik yang dapat diketahui melalui tingkah laku dan pola pikir mereka dalam kehidupan sehari-hari, maka dari itu pembelajaran pendidikan agama Islam bukan menjadi tanggung jawab guru Pendidikan agama Islam saja, melainkan membutuhkan dorongan dan motivasi dari pihak sekolah, masyarakat, serta dukungan 
Peran Pendidikan Islam terhadap Pembentukan Karakter Disiplin Peserta Didik

Oleh: Unik H Salsabila, Annisa S Hutami, Safira A

Fakhiratunnisa, Wulan Ramadhani, Yuike Silvira

dari orang tua peserta didik juga menjadi kunci penting.

Pihak sekolah harus dapat melakukan koordinasi dan komunikasi pola pembelajaran pendidikan agama Islam kepada pihak yang sudah disebutkan sebagai suatu komunitas yang saling mengawasi serta memotivasi agar terciptanya karakter peserta didik yang berbudi pekerti luhur serta berakhlak. Memberikan pelajaran tentang akidah akhlak yang merupakan hal dasar paling utama dalam pembentukan karakter disiplin peserta didik. Itulah pentingnya pembelajaran pendidikan agama Islam yang dapat menuntun terbentuknya anak yang berpengetahuan tinggi, agamis dan berkepribadian. Maka benar apabila pelaksanaan pendidikan agama Islam di sekolah merupakan kunci pokok dalam pendidikan karakter peserta didik. Pendidikan agama Islam mengajarkan betapa pentingnya penanaman akhlak terutama mengajarkan kesadaran beragama pada peserta didik. Pendidik mengajarkan tentang dasar kagamaan yang didapat dari akidah, mengajarkan tentang hukum dalam beribadah pada sehari-hari didapat dari fikih, mengajarkan tentang pedoman perilaku manusia yang buruk ataupun baik didapat dari akhlak, mengajarkan tentang keteladanan hidup didapat dari sejarah, dan mengajarkan tentang pedoman hidup didapat dari Al-Qur'an dan as-Sunnah. ${ }^{18}$

Hal tersebut mampu menunjukkan jika pembelajaran pendidikan agama Islam mempunyai peranan penting dalam pembentukan karakter peserta didik. Oleh karena itu pendidikan Islam harus mendapatkan perhatian yang lebih dari pihak sekolah. Berkaitan dengan karakter, pembelajaran pendidikan agama Islam perlu dijabarkan sesuai dengan sasaran atau tujuan. Sasaran yang dituju bukan hanya untuk menghasilkan bahan pelajaran saja, namun lebih difokuskan untuk meningkatkan kualitas pendidikan karakter.

Pendidikan agama Islam pada lembaga pendidikan merupakan sarana dalam mengembangakan karakter peserta didik agar menjadi manusia yang dapat bersanding dengan manusia lainnya pada lingkungan masyarakat. Upaya yang harus dilakukan oleh lembaga pendidikan, kepala sekolah, serta pendidik dalam membentuk karakter peserta didik yaitu harus memiliki langkah-langkah yang tepat agar dapat memperoleh keberhasilan dalam proses pengajaran untuk membentuk karakter peserta didik di lembaga pendidikan. Guru

\footnotetext{
18 Nur Ainiyah, "Pembentukan Karakter Melalui Pendidikan Agama Islam," Jurnal Al-Ulum 13, no. 1 (2013): 25-38.
} 
Peran Pendidikan Islam terhadap Pembentukan Karakter

Disiplin Peserta Didik

Oleh: Unik H Salsabila, Annisa S Hutami, Safira A

Fakhiratunnisa, Wulan Ramadhani, Yuike Silvira

pendidikan agama Islam harus mampu

membentuk karakter peserta didik yang berakhlak mulia serta dapat menerapkan nilai-nilai ajaran Islam dalam kehidupan sehari-hari. ${ }^{19}$ Banyak ditemukan peserta didik tidak berakhlak baik dan kurang bermoral bukan karena kesalahan seorang pendidik melainkan memang karakter itulah yang dimiliki peserta didik. Dengan demikian kewajiban seorang pendidik adalah membantu dan membina peserta didik agar menjadi individu yang baik dan disiplin.

Pendidik mengajarkan karakter disiplin pada peserta didik yakni dengan melakukan pembiasaan. Fungsi dari pembiasaan yaitu sebagai penguat dari objek ataupun substansi yang sudah masuk ke dalam hati penerima pesan (peserta didik). Proses dari pembiasaan dipusatkan pada pengalaman langsung yang berguna sebagai perekat antara perbuatan karakter serta diri seseorang. Fungsi lain dari pembiasaan ialah sebagai penjaga akhlak yang telah menyatu dalam diri seseorang, serta akan melahirkan interpretasi yang mendalam dan meluas, sehingga seseorang semakin yakin dan mantap untuk memegang objek akhlak yang telah diyakini.

${ }^{19}$ Nasrullah, "Pembentukan Karakter Siswa Melalui Pendidikan Agama Islam," Jurnal Salam 18, no. 1 (2015): 67-82, www.kemdiknas.go.id.
Pembiasaan

ini

sangatlah

dibutuhkan dalam pembentukan karakter, sebab hati seseorang mudah berubah meskipun terlihat perilaku yang dilakukan sudah menyatu pada dirinya. ${ }^{20}$ Pembiasaan yang dimaksud ialah setelah peserta didik paham dan menerapkan suatu tindakan, baik yang sudah pendidik ajarkan kemudian dilakukanlah pembiasaan, dengan cara tersebut yang dilakukan secara berulang kali maka peserta didik mampu terbiasa melakukan hal baik. Pada upaya dalam pembentukan karakter disiplin peserta didik, baiknya dibiasakan agar peserta didik mematuhi peraturan-peraturan yang ada di sekolah maka dapat terwujud karakter disiplin pada peserta didik. Disiplin terhadap peraturan yang ada di sekolah bisa dilihat dari keseharian peserta didik saat di sekolah. Seperti tidak terlambat saat datang ke sekolah, mengumpulkan tugas dengan tepat waktu, serta memakai seragam sesuai dengan tata tertib sekolah.

Selanjutnya, melalui metode keteladanan dalam Islam sendiri suri teladan umat Islam adalah Nabi Muhammad Shallallahu Alaihi Wasallam di mana Nabi memiliki sifat dan akhlak yang baik serta Nabi memiliki sikap disiplin yang harus ditiru oleh umatnya.

\footnotetext{
20 Mohammad Nasirudin, "Pendidikan Tasawuf," Semarang: Rasail Group, 2010.
} 
Peran Pendidikan Islam terhadap Pembentukan Karakter

Disiplin Peserta Didik

Oleh: Unik H Salsabila, Annisa S Hutami, Safira A

Fakhiratunnisa, Wulan Ramadhani, Yuike Silvira

Berkaitan dengan itu, seorang pendidik memiliki peranan penting dan sangat mempengaruhi keberhasilan pembentukan karakter peserta didik. Peserta didik akan mengenali, menyontoh, serta menerapkan perilaku yang dilakukan oleh figur idolanya. Saat peserta didik menjumpai suatu teladan yang baik di lingkungannya, maka ia akan menerima nilai-nilai kebaikan yang dapat dikembangkan menjadi tingkah laku dan akhlak yang terpuji. ${ }^{21}$

Apa yang telah dicontohkan pendidik pada peserta didik, akan memberi kesan pada diri mereka sehingga dapat membenahi sikap serta tingkah laku, memberi arahan, dan menyiapkan mereka dalam membangun kehidupan untuk menjadi anggota masyarakat. ${ }^{22}$ Pendidik dapat membina peserta didik dengan keteladanan agar mereka memiliki sikap yang kukuh. Agar mengetahui adanya tanda keteladanan dalam pembentukan karakter, salah satunya bisa ditinjau melalui adakah model peran yang terdapat pada pribadi pendidik. Begitu pula adakah terdapat contoh dan kebijakan serta tingkah laku yang bisa diteladani oleh peserta didik

\footnotetext{
21 Mursidin, "Moral Sumber Pendidikan: Sebuah Formula Pendidikan Budi Pekerti Di Sekolah/Madrasah," Bogor: Ghalia Indonesia, 2011.

22 Abdul Majid and Dian Adyani, "Pendidikan Karakter Persepektif Lslam," Bandung: Remaja Rosdakarya, 2012.
}

dilihat dari kelembagaannya, sehingga apa yang mereka pahami tentang nilai-nilai tersebut memang bukan sesuatu yang asing dari kehidupan mereka. ${ }^{23}$

$$
\text { Pemberian nasihat dalam }
$$
pembentukan karakter melalui pendidikan Islam pun perlu diberikan kepada para peserta didik. Pada dasarnya, masingmasing individu punya kemampuan untuk bisa menyerap kata-kata yang didengarnya, meskipun perlu adanya pengulangan yang dilakukan beberapa kali agar menyerap ke dalam jiwa. Dengan demikian, memberikan nasihat adalah salah satu cara yang jitu dalam menegakkan karakter disiplin kepada peserta didik. Melalui metode nasihat memberikan dampak yang cukup besar kepada peserta didik sehingga dapat menyadari akan pengertian suatu dasar, menghiasinya dengan budi pekerti baik, membekalinya dengan prinsip-prinsip keislaman, serta menggerakan peserta didik menuju harkat dan martabat yang luhur. ${ }^{24}$

Berkaitan dengan hal tersebut implementasi dari metode nasihat sudah dicantumkan di dalam al-Qur'an yaitu pada surah Luqman ayat 13, saat Luqman

\footnotetext{
${ }^{23}$ Doni Koesoema A, Pendidikan Karakter: Strategi Mendidik Anak Di Zaman Global, Jakarta: PT Grasindo, 2011.

24 Maskuri, "Pendidik Karakter Disiplin Di Lingkungan Sekolah," Jurnal Tawadhu 2, no. 1 (October 18, 2018): 340-363, https://ejournal.iaiig.ac.id/index.php/TWD/article/v iew/3.
} 
Peran Pendidikan Islam terhadap Pembentukan Karakter Disiplin Peserta Didik

Oleh: Unik H Salsabila, Annisa S Hutami, Safira A

Fakhiratunnisa, Wulan Ramadhani, Yuike Silvira

menyampaikan nasihat pada anaknya agar tidak menyekutukan Allah SWT. Akan tetapi, dalam pemberian nasihat sebaiknya diiringi dengan situasi yang menyegarkan dan menyenangkan, agar perilaku disiplin benar-benar dilandaskan oleh ketulusan yang tinggi, penerimaan, serta pemahaman.

Selanjutnya ialah pemberian teguran. Menurut Binti Maunah, pemberian teguran kepada peserta didik yang kurang disiplin sudah menjadi sesuatu hal yang lumrah apabila manusia merupakan tempat salah dan lupa. Sehubungan dengan itu, maka untuk berbuat salah memiliki potensi yang cukup besar. Berbagai penyelewengan pada norma atau hukum menjadi suatu hal yang tidak memungkinkan untuk dihindari. Maka dari itu, perlu adanya peringatan atau teguran serta koreksi untuk mencegah timbulnya masalah yang lebih jauh lagi. Teguran yang dimaksud bisa berupa isyarat-isyarat dan juga kata-kata. ${ }^{25}$

\section{Kesimpulan}

Pendidikan Islam sangat berperan penting dalam pembentukan karakter disiplin peserta didik. Karena pendidikan Islam merupakan suatu upaya agar membuat peserta didik menjadi lebih disiplin, beradab, sopan santun dan alim serta membantu para peserta didik menjadi

${ }^{25}$ Maskuri. individu yang insan kamil dan memiliki akhlakul karimah. Peran pendidikan Islam dalam pembentukan karakter disiplin dapat dilihat melalui materi pelajaran Pendidikan Agama Islam (PAI) yang dikembangkan dalam keseharian peserta didik di sekolah, melalui metode keteladanan yang dicontohkan oleh pendidik kepada para peserta didik, melakukan pembiasaan perilaku disiplin, serta memberikan nasihat serta teguran kepada para peserta didik sesuai dengan kaidah serta ajaran-ajaran yang ada pada agama Islam.

\section{Daftar Pustaka}

Ainiyah, Nur. "Pembentukan Karakter Melalui Pendidikan Agama Islam." Jurnal Al-Ulum 13, no. 1 (2013): 2538.

Annisa, Fadillah. "Penanaman Nilai-Nilai Pendidikan Karakter Disiplin Pada Siswa Sekolah Dasar." Perspektif Pendidikan Dan Keguruan 10, no. 1 (2019): 69-74.

Fitriyah, Nur Lailatul, and Nur Ulwiyah. "Internalisasi Nilai-Nilai Pendidikan Islam Dalam Pembentukan Karakter Siswa SMP." Jurnal Pendidikan Islam 3, no. 2 (2019): 247-269.

Koesoema A, Doni. Pendidikan Karakter: Strategi Mendidik Anak Di Zaman Global. Jakarta: PT Grasindo, 2011.

Majid, Abdul, and Dian Adyani. "Pendidikan Karakter Persepektif Lslam." Bandung: Remaja Rosdakarya, 2012.

Maskuri. "Pendidik Karakter Disiplin Di Lingkungan Sekolah." Jurnal 
Peran Pendidikan Islam terhadap Pembentukan Karakter Disiplin Peserta Didik

Oleh: Unik H Salsabila, Annisa S Hutami, Safira A

Fakhiratunnisa, Wulan Ramadhani, Yuike Silvira

Tawadhu 2, no. 1 (October 18, 2018): 340-363.

https://ejournal.iaiig.ac.id/index.php/

TWD/article/view/3.

Mujib, Abdul, and Jusuf Mudzakkir. Ilmu Pendidikan Islam. Jakarta: Kencana Prenada Media Group, 2007.

Mursidin. "Moral Sumber Pendidikan: Sebuah Formula Pendidikan Budi Pekerti Di Sekolah/Madrasah." Bogor: Ghalia Indonesia, 2011.

Nasional, Departemen Pendidikan. Kamus Besar Bahasa Indonesia. Jakarta: Gramedia Pustaka Utama, 2019.

Nasir, Ridlwan. "Mencari Tipologi Format Pendidikan Ideal: Pondok Pesantren Di Tengah Arus Perubahan." Yogyakarta:Pustaka Pelajar, 2010.

Nasirudin, Mohammad. "Pendidikan Tasawuf." Semarang: Rasail Group, 2010.

Nasrullah. "Pembentukan Karakter Siswa Melalui Pendidikan Agama Islam." Jurnal Salam 18, no. 1 (2015): 67-82. www.kemdiknas.go.id.

Rachman, Aulia, and Murniati Agustian. "Meningkatkan Kedisiplinan Siswa Melalui Pengelolaan Kelas Di SDN 23 Pagi Palmerah Jakart." Jurnal Perkotaan 8, no. 2 (2016): 75-93.

Rahmat, Nur, Sepriadi Sepriadi, and Rasmi Daliana. "Pembentukan Karakter Disiplin Siswa Melalui Guru Kelas Di Sd Negeri 3 Rejosari Kabupaten Oku Timur." JMKSP (Jurnal Manajemen, Kepemimpinan, Dan Supervisi Pendidikan) 2, no. 2 (2017): 229-244.

Rohmadi, Syamsul Huda. Pengembangan Kurikulum Pendidikan Agama Islam. Yogyakarta: Araska, 2012.
Samani, Muchlas, and Hariyanto. Konsep Dan Model Pendidikan Karakter. Bandung: PT Remaja Rosdakarya, 2011.

Siregar, Maragustam. Filsafat Pendidikan Islam: Menuju Pembentukan Karakter Menghadapi Arus Global. Yoyakarta: Kurnia Kalam Semesta, 2015.

Suhada, H, Arief Saptono, and Ageng Setiani Rafika. "Pengaruh Pendidikan Agama Islam Terhadap Perilaku Akhlak Siswa (Karakter)." Jurnal Cices 4, no. 2 (2018): 228-244.

Suradi. "Pembentukan Karakter Siswa Melalui Penerapan Disiplin Tata Tertib Sekolah." BRILIANT: Jurnal Riset Dan Konseptual 2, no. 4 (November 13, 2017): 522-533. https://doi.org/10.28926/briliant.

Syamsul, Kurniawan. "Pendidikan Karakter." Yogyakarta: Ar-Ruzz. Media, 2014.

Tafsir, Ahmad. Ilmu Pendidikan Dalam Perspektif Islam. Bandung: PT Remaja Rosdakarya, 2014.

Wibowo, Agus. "Manajemen Pendidikan Karakter Di Sekolah." Yogyakarta:Pustaka Pelajar, 2017.

Yusdiani, Nurmila, Umar Sulaiman, and Yusuf Seknun. "Penanaman Budaya Disiplin Terhadap Peserta Didik Kelas VI MIS GUPPI Laikang Kecamatan Kajang Kabupaten Bulukumba." Jurnal Inspiratif Pendidikan 7, no. 2 (2018): 233-252.

Zakaria Ansori, Yoyo. "Penguatan Karakter Disiplin Siswa Melalui Peranan Guru Di Sekolah Dasar." Jurnal Elementaria Edukasia 3, no. 1 (2020): 126-135. 